\title{
EFFECTIVENESS OF ANTIBODY VS ANTIGEN BASED DETECTION METHOD AND THE SCREENING APPROACHES TO COMBAT COVID-19
}

\author{
BIBI NUR BAZLINI BAHARUN AND SABREENA SAFUAN* \\ Pusat Pengajian Sains Kesihatan, Kampus Kesihatan, Universiti Sains Malaysia, 16150 Kubang Kerian, Kelantan. \\ *Corresponding author: sabreena@usm.my \\ Submitted final draft: 24 November 2020 Accepted: 24 November $2020 \quad$ http://doi.org/10.46754/jssm.2021.01.004
}

\begin{abstract}
The spreading of novel SARS-CoV-2 coronavirus (COVID-19) had infected $41,570,883$ people worldwide, with infection cases in Malaysia reaching 24,514 cases on 23rd October 2020. COVID-19 has been associated with severe lower respiratory tract infections, acute respiratory distress syndrome, and death. In response to this global emergency situation, clinical research and interventions in treating COVID-19 are emerging at an unprecedented rate. Currently, there are two types of test that were used to detect the presence of COVID-19: antigen-based and antibody-based detection tests, each with specific advantages and disadvantages which is the focus of this article. In addition, issue on whether rapid mass screening is better compared to the targeted screening to halt COVID-19 infection is also discussed. We conclude that antigen-based detection kit using Real Time Polymerase Chain Reaction (RT-PCR) has high specificity and sensitivity compared to other methods. In a country with lack resources, manpower and facilities, targeted screening can be opted as this method is equally effective to contain COVID-19 spreading when compared with rapid mass screening.
\end{abstract}

Keywords: Coronavirus, antigen-based kit, antibody-based kit, mass screening, targeted screening.

Abbreviations: [SARS-CoV-2 coronavirus (COVID-19), Reverse TranscriptionPolymerase Chan Reaction (RT-PCR), Loop Mediated Isothermal Amplification (LAMP), Enzyme-Linked Immunosorbent Assay (ELISA)]

\section{Introduction}

The emergence of COVID-19 pandemic at the end of 2019 has caused significant alarm all over the world. As of $23^{\text {rd }}$ October 2020, COVID-19 had infected 41,570,883 people worldwide with recovery at 24,254,178 and $1,134,940$ deaths (World Health Organization, 2020). Malaysia, at that time, had 24,514 positive cases, with 15,884 recovery and 214 death cases. COVID-19 causes $5.2 \%$ worldwide mortality rate leading to an urgent need of effective treatment (Puja et al., 2020). In response to this global emergency situation, clinical trial research studying the efficacy and safety of clinical interventions in treating COVID-19 are emerging at an unprecedented rate. Currently, there are over 500 clinical trials registered at the World Health Organisation (WHO), Centre of Disease Control and Prevention (CDC), Institute of Medical Research Malaysia and at various other international and national clinical trials registry site (Kristian et al., 2020).

COVID-19 is a $\beta$-coronavirus that could cross species barrier and evolve to become human pathogen. The genome of this spherically shaped virus encodes four main structural proteins which is the surface spike (S) glycoprotein, the membrane (M) protein, the small envelope (E) glycoprotein, and the nucleocapsid $(\mathrm{N})$ protein. E glycoprotein participates in the assembling, budding, and intracellular trafficking of infectious virions while the $\mathrm{N}$ protein forms helical ribonucleoproteins during the packaging of the RNA genome, regulating viral RNA synthesis during replication and transcription of the virus (Cong et al., 2020). Co-localisation and interaction between $M$ protein and $E$ glycoprotein were probably the most wellestablished protein-protein interaction between the COVID-19 structural proteins. Co- 
expression of $\mathrm{M}$ protein and $\mathrm{E}$ glycoprotein is sufficient for virus-like particle formation and release (Schoeman \& Fielding, 2019). The S glycoprotein is present on the surface of the virus which binds to the receptor on host cell and mediates the cell membrane fusion upon entering the host cell (Zhou et al., 2020; Wu et al., 2020). In the host cell, the virus releases its RNA and forms abundant copies during the infection process. COVID-19 produces an acute viral infection in humans with an incubation period of 3 days (Guan et al., 2020). The time gap between symptom onsets to the development of acute respiratory distress syndrome took about 9 days among the initial cases (Huang et al., 2020). Common clinical manifestations of COVID-19 virus infection include fever, dry cough, dyspnea, chest pain, fatigue and myalgia (Wang et al., 2020; Zhu et al., 2020). Less common symptoms include headache, dizziness, abdominal pain, diarrhea, nausea, and vomiting (Huang et al., 2020; Wang et al., 2020). Some patients progressed rapidly with Acute Respiratory Stress Syndrome (ARDS) and septic shock, which eventually followed by multiple organ failure (Chen et al., 2020).

Up to date, there are no specific antiviral treatments for COVID-19. Isolation and supportive care which include oxygen therapy, fluid management, and antibiotics treatment for secondary bacterial infections is the current recommendation in managing COVID-19 infection (Habibzadeh \& Stoneman, 2020). The initial management of mass public health crisis is focused on the early detection of suspected cases to contain the disease spread by immediate isolation and infection control measures (WHO, 2020). While mass screening has been proven effective to detect infection in a large number of individuals, Malaysia has opted for targeted testing in high- risk areas and individuals, which is said to be equally effective to mass screening. This article will focus on the types of test used to detect COVID-19 titre in suspected individuals and the pros and cons of using mass screening vs targeted approach to combat COVID-19 infection.

\section{Method}

This article will focus on the types of test used and the pros and cons of both strategies, mass screening and targeted approach, in reducing the rate of COVID-19 infection worldwide. The methodology used was literature search on published articles using 6 search engines which include PubMed, Science Direct, Elsevier, Google Scholar, Google and Web of Science. Keywords used in these search engines were Coronavirus and synonym, RT-PCR, LAMP, Lateral flow assay, ELISA and mass and targeted screenings. A total of 78 articles were identified from the literature using different search engines. The title and abstract of the article were screened after which 30 articles were excluded because of the non-suitability of topics. 48 full text articles were examined and out of that, 25 articles were excluded because their content was related to the COVID-19 virus structure instead of the testing methodology. 23 articles were included for the final review. Information and data were also obtained from official government websites (Ministry of Health Malaysia, Center for Disease Control and Prevention, World Health Organisation and Malaysian National Security Council), newspaper articles (New Straits Times Malaysia, The Times UK, Fortune UK, The Guardian Germany and Middle East Eye Turkey) and online articles (Bloomberg, Reuters US, The Telegraph India, NPR South Korea).

\section{Result and Discussion}

\section{Types of COVID-19 testing used worldwide}

There are two types of test that had been used to detect COVID-19 virus in human: antigen-based and antibody-based detection tests. Antigenbased detection test detects the presence of the virus (Kile et al., 2020) while antibody- based detection tests for the presence of the antibodies (Kumar et al., 2020) which are proteins produced by the immune system to fight COVID-19 viruses. Another option, which is less specific is via CT scan to detect lung damage or by low lung oxygen take up (Harapan et al., 2020). 
Majority of the COVID-19 virus detection tests are carried out by using Reverse Transcription-Polymerase Chain Reaction (RTPCR), as this method directly detects the presence of RNA virus in patients' sample (WHO, 2020; CDC, 2020). RT-PCR test is

highly specific and sensitive as it can detect even a single part of the virus genetic material which usually are the $\mathrm{S}$ protein, $\mathrm{N}$ protein or $\mathrm{E}$ glycoprotein and then amplify it. The average detection time using RT-PCR is 3 to 4 hours, however, it might take longer depending on the transportation time to the diagnostic laboratory. RT-PCR product, test and machine technology are widely available globally with all- in-one kit developed for RT-PCR. Currently, the Ministry of Health Malaysia is using RT-PCR as the main detection test for COVID-19 with the support of serology testing (Ministry of Health Malaysia, 2020).

Loop Mediated Isothermal Amplification (LAMP) is another technology using the same principle as RT-PCR but instead of using temperature cycle change, LAMP is run at a constant temperature of $60-65^{\circ} \mathrm{C}$ (Kent, 2020). The DNA amplification of the virus can be detected through the production of a chemical called magnesium pyrophosphate. The chemical reaction causes the solution mixture to become cloudy which can be observed by the nakedeye. Thus, it allows for easy diagnosis of COVID-19 by the scientists and clinicians (Kile et al., 2020). Besides, LAMP produces a higher amount of DNA and the result could have been obtained in 2-3 hours only. It is more cost-effective compared to the RT-PCR. Both antigen-based testing could only detect individuals that are currently being infected with the virus thus, it is possible to overlook the patient that has cleared and recovered from the virus (CDC, 2020).

Lateral flow assay is an antibody detectionbased assay which detects $\operatorname{IgG}$ or IgM against COVID-19 virus that is present in the human blood. When an individual is infected with the COVID-19 virus, antibodies (IgM) with intermediate strength binding to the virus are generated by the immune system to fight against these viruses. IgM could be detected from day- 5 post-infection sets in and on the $8^{\text {th }}$ day another antibody ( $\operatorname{IgG}$ ) with a high binding strength is produced by the immune system for a more rapid clearance of the virus. These antibodies could remain in the blood for months after the virus or disease is cleared (Dougherty, 2020; Puja et al., 2020). The antibody testing only takes about 30 minutes and it does not require expensive equipment, machine or extensive training (Kile et al., 2020). Detection could be done not only in individuals with current infection but also could differentiate individuals with a history of COVID-19 infection. However, since the production of antibodies varies between individuals and might not be detectable in early infections, the percentage of false negative is high. In addition, the sensitivity of lateral flow assay is only in the range of $34 \%$ to $84 \%$ accuracy (WHO, 2020) and each device could only be used for one sample.

The Enzyme-Linked Immunosorbent Assay (ELISA) is a commonly used biochemical technique to detect antigens or antibodies (Wu et al., 2020). ELISA usedenzyme-linked-antibody which is attached to the COVID-19 virus molecules leading to colour changes. The result of ELISA testing could be produced within 1 to 3 hours of sample collection. (Alfonso et al., 2020). Other than that, ELISA testing could be done with multiple samples for a larger number of patients in a single run of the test (Wang et al., 2020). However, the ELISA testing for COVID19 virus is still not well established and is at the earlier phase of research (Shereen et al., 2020).

Table 1 shows the problems faced by countries using the COVID-19 test kits. Based on this table, most of the problems were detected with the usage of antibody-based detection kits which are easy to use and are less time consuming, compared to the antigen-based detection kits but have a high rate of error and inaccuracy. Therefore, Malaysia has opted to use the RT-PCR method due to higher specificity and sensitivity of the antigen-based detection kit. 
Table 1: Country that had encountered accuracy problem with the testing kit for COVID-19

\begin{tabular}{|c|c|c|}
\hline Country (Reference) & Types of kits & Detail of the problem \\
\hline China (Lulu, 2020) & $\begin{array}{l}\text { PCR Antigen- } \\
\text { Based test }\end{array}$ & Accuracy problem with the testing kit \\
\hline $\begin{array}{l}\text { United States (Andrew et } \\
\text { al., 2020) }\end{array}$ & Antigen-based test & Testing kit developed by CDC had some flaws. \\
\hline $\begin{array}{l}\text { Spain (Roxanne \& Inti, } \\
\text { 2020) }\end{array}$ & $\begin{array}{l}\text { PCR Antigen-based } \\
\text { test }\end{array}$ & $\begin{array}{l}\text { The results obtained from the testing kits purchased } \\
\text { from Shenzen Biotechnology Co Ltd were found to be } \\
\text { inaccurate. The company stated that the inaccuracy } \\
\text { may be due to the failure in sample collection or kit } \\
\text { usage. }\end{array}$ \\
\hline $\begin{array}{l}\text { Czech Republic (Vojtech, } \\
\text { 2020) }\end{array}$ & Antibody-based test & $\begin{array}{l}80 \% \text { of the kits purchased from China gave out false- } \\
\text { positive and negative results. }\end{array}$ \\
\hline $\begin{array}{l}\text { Slovakia (Andrea } \\
\text { Radoslav, 2020) }\end{array}$ & Antibody-based test & $\begin{array}{l}\text { Prime Minister Matovic stated that } 1,200,000 \text { kit } \\
\text { purchased from China were also found to be } \\
\text { inaccurate. }\end{array}$ \\
\hline Turkey (Ragip, 2020) & Antibody-based test & $\begin{array}{l}\text { Turkish Health Ministry said that the testing kit } \\
\text { purchased from China had a high error rate with only } \\
30 \%-35 \% \text { accuracy. }\end{array}$ \\
\hline $\begin{array}{l}\text { United Kingdom (Chris, } \\
\text { 2020) }\end{array}$ & Antibody-based test & $\begin{array}{l}\text { In early April } 2020 \text {, the country purchased } 3.5 \text { million } \\
\text { test kits from China but announced those were not } \\
\text { usable. }\end{array}$ \\
\hline India (Pti, 2020) & Antibody-based test & $\begin{array}{l}\text { Indian Council of Medical Research advised the Indian } \\
\text { state to stop using the rapid antibody test kit purchased } \\
\text { from China. The health ministry said the kits gave only } \\
5.4 \% \text { accurate result against the expectation of } 90 \% \\
\text { accuracy. }\end{array}$ \\
\hline
\end{tabular}

\section{Mass screening vs targeted screening of COVID-19}

Due to the wide spread of COVID-19 virus, there is a high demand of the testing kits worldwide. This situation had caused backlogs of testing kits, swab supplies and chemical reagents in the affected countries. Producer countries were unable to supply enough testing kits to meet demands and recommendation for testing by the health experts. Due to this problem and the massive budget that is required, certain countries opted for targeted screening instead of mass screening.

\section{Mass screening of COVID-19}

As part of public health mitigation strategy on COVID-19, the World Health Organisation has recommended rapid mass screening followed by contact tracing of positive infected cases. Mass screening aims to detect and treat all COVID-19 infections in a population to limit further human to human transmission thereby stopping the chain of this virus. The importance of mass screening supersedes targeted screening as some of the asymptomatic COVID-19 cases could be overlooked if only the targeted screening method is being used. In countries where asymptomatic cases are high, rapid mass screening should be used instead of targeted screening. South Korea is an example where a well-organised rapid mass testing is the best strategy to curb COVID-19 infection. Due to this strategy, South Korea has succeeded in containing COVID-19 infection from 800 daily cases in March to a sharp drop to less than 50 cases daily with a rate of 0.21 daily test per 1000 people (Figure 1). No lockdown was imposed on South Korean showing that high diagnostic capacity is the key to their success. Other countries imposing the mass testing strategy is shown in Table 2 . 
Table 2: COVID-19 testing capacity among countries

\begin{tabular}{|c|c|c|}
\hline Country & Testing capacity & Result \\
\hline $\begin{array}{l}\text { South Korea (South Korea CDC, } \\
\text { 2020) }\end{array}$ & 0.21 daily test per 1000 people & $\begin{array}{l}\text { Sharp decline in cases from } 800 \\
\text { cases per day to less than } 50 \text { cases }\end{array}$ \\
\hline $\begin{array}{l}\text { China (Centre for Health } \\
\text { Protection China, 2020) }\end{array}$ & 0.51 daily test per 1000 people & $\begin{array}{l}\text { Declining from } 15,141 \text { cases to } 52 \\
\text { cases per day }\end{array}$ \\
\hline Germany (ROCH,2020) & 0.64 daily test per 1000 people & $\begin{array}{l}\text { Gradual decline from } 5940 \text { cases to } \\
447 \text { cases per day }\end{array}$ \\
\hline $\begin{array}{l}\text { Iceland (Public Health of } \\
\text { Iceland,2020) }\end{array}$ & 0.21 daily test per 1000 people & $\begin{array}{l}\text { Great decline from } 99 \text { cases daily } \\
\text { to } 0 \text { cases per day }\end{array}$ \\
\hline $\begin{array}{l}\text { Italy (Ministero della Salute, } \\
\text { 2020) }\end{array}$ & 0.46 daily test per 1000 people & $\begin{array}{l}\text { Gradual decline from } 6557 \text { cases } \\
\text { to } 577 \text { cases per day }\end{array}$ \\
\hline
\end{tabular}

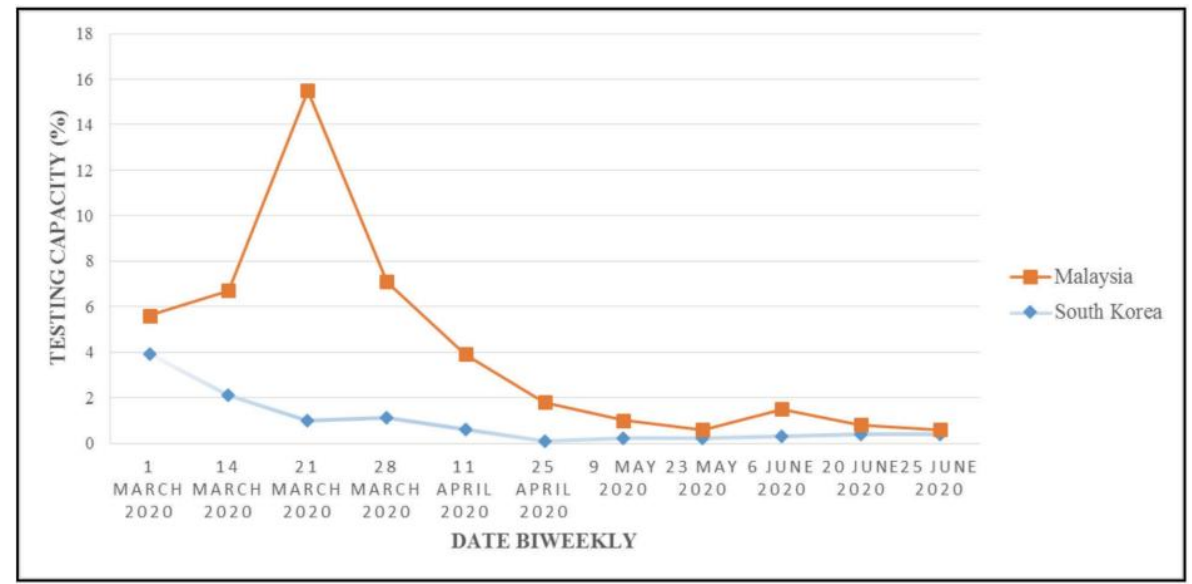

Figure 1: COVID-19 testing capacity conducted per confirmed case of COVID-19 by South Korea compared to Malaysia

Despite the proven success of a large- scale testing strategy, it also requires large scale equipment and personnel to conduct the analyses as to prevent backlog of cases. In addition, this effort requires a large budget for the procurement of materials, employing trained personnel, building the laboratory capacity from scratch and logistic intervention to access the whole population (OECD, 2020). Germany has a large medical diagnostic industry, with a capacity of over 100 testing laboratories providing the technology and infrastructure to enable rapid increase in testing and kit production (Department of Health and Social Care, 2020). The President of the Robert Koch Institute Germany stated that Germany possess an overall capacity of 160,000 test per week through the lab test and drive-in test method (Oltermann, 2020). In South Korea, testing capacity mostly in private sector labs, was built up by the South Korean government, apart from their drivethrough centers which are also transformed into COVID-19 testing facility. (Anthony, 2020). Due to this, WHO suggested that ramping up the testing programmes is the best way to slow down the advance of COVID-19 pandemic (WHO, 2020).

\section{Targeted screening of COVID-19}

In a country where rapid mass screening was not possible due to various factors, targeted screening was chosen. Targeted screening involves specific area of screening with significant daily increase of COVID-19 infection. It is made compulsory 
for people in that targeted area (termed red area) to undergo COVID-19 tests. With this method, the constraint towards laboratory facilities, manpower and budget could be slightly lifted compared to the mass screening method.

In Malaysia, mass testing was done at the targeted area with an enhanced movement control order (EMCO) and this approach produces a high-impact and good outcome in a short period of time. Until $23^{\text {rd }}$ October 2020, Malaysia's daily testing capacity was at 41,354 from 60 laboratories in the country which counts to 13 tests per 1,000 people. (Ministry of Health Malaysia, 2020). The Health Ministry of Malaysia is also planning to add five more laboratories to boost its testing capacity. Malaysia has also procured antigen rapid test from South Korea which could produce results within 30 to 45 minutes. Malaysia's coronavirus testing rate of per 1,000 population is lower than Singapore's which reported a rate of 25 tests per 1,000 population, but much higher than Indonesia's 0.5 tests per 1,000 people. Meanwhile, the United States' testing rate is 16 people per 1,000, while the United Kingdom's is 10 per 1,000 people. In the United Kingdom, the government encouraged their life sciences company to venture into diagnostic in order to scale up their testing capacity. By the end of April, the United Kingdom managed to increase their testing capacity to 250,000 per day (Charisius, 2020).

\section{Conclusion}

In summary, both the mass and targeted screening methods used by the affected countries had been proven equally effective in controlling the spread of COVID-19. Currently, there are no promising clinical treatment against COVID-19. However, researchers are working to develop efficient therapeutic strategies to cope with the virus. Until effective COVID-19 vaccine is ready, population testing, be it mass testing or targeted testing by using antigen-based detection method is most effective to reduce disease transmission. Nevertheless, as each test type has its own 'pros and cons' probably a combination of testing types used at different times might be useful for patient management and population pandemic control of COVID-19.

\section{Acknowledgements}

This work was supported by the Research University (RU) Grant Universiti Sains Malaysia [Grant Number: 1001/PPSK/8012315].

\section{Reference}

Ai, T., Yang, Z., Hou, H., Zhan, C., Chen, C., \& Lv W. (2020). Correlation of chest CT And RT-PCR testing in coronavirus disease 2019 (COVID-19) in China: A report of 1014 Cases. Radiology, 296(2), E32-E40.

Alfonso, J. R., Jaime, A., Cardona, O., Estefanía, G., Rhuvi, V.P., Yeimer, H. R., Juan, P. E., Lucia, E. A., \& Katterine, B. A. (2020). Clinical, laboratory and imaging features of COVID-19: A systematic review and metaanalysis. Travel Medicine and Infectious Disease, 34, 101623.

Andersen, K. G., Rambaut, A., \& Lipkin, W. I. (2020). The proximal origin of SARS- Cov2. Nature Medicine, 323(11).

Andrea D., \& Radoslav T. (2020). Europe turned to China for coronavirus testing help. Why some are now regretting it. Fortune. Retrieved from https:// fortune.com/2020/04/01/europe-chinacoronavirus-testing-help-regret/

Andrew R., John H., \& Tonya, A. (2020). State figures on testing raise questions about efforts to contain outbreak. The Boston Globe. Retrieved from https:// www.bostonglobe.com/2020/03/14/metro/ baker-sets-up-virus-command-center

Anthony K. (2020). Experts Credit South Korea's Extensive Testing For Curbing Coronavirus Spread. NPR. Retrieved from https://www.npr. org/2020/03/12/815097813/experts-credit- 
south-koreas-extensivetesting-for-curbingcoronavirus-spread

Center for Disease Control and Prevention (2020). Testing for COVID-19. Retrieved from https://www.cdc.gov/ coronavirus/2019-ncov/symptoms-testing/ testing.html.

Charisius, H. (2020). Covid-19: Wie gut testet Deutschland?. Retrieved from https:// www.sueddeutsche.de/gesundheit/covid-19coronavirus-testverfahren 1.4855487 .

Chen, N., Zhou, M., Dong, X., Qu, J., Gong, F., \& Han, Y. (2020). Epidemiological and clinical characteristics of 99 cases of 2019 novel coronavirus pneumonia in Wuhan, China: A descriptive study. The Lancet, 395,507-13.

Chowell, G., Abdirizak, F., \& Lee, S. (2015). Transmission characteristics of MERS and SARS in the healthcare setting: A comparative study. BMC Medicine, 3(13).

Chris S. (2020). Britain has millions of coronavirus antibody tests, but they don't work. The Times UK. Retrieved from https://www.thetimes.co.uk/article/britainhas-millions-of-coronavirus-antibodytests-but-they-don-t-work-j7kb55g89

Cong, Y., Ulasli, M., Schepers, H., Mauthe, M., V'Kovski, P., Kriegenburg, F., Thiel, V., de Haan, C. A. M., \& Reggiori, F. (2020). Nucleocapsid protein recruitment to replication-transcription complexes plays a crucial role in coronaviral life cycle. Journal of Virology, 94(9).

Department of Health and Social Care. (2020). Coronavirus (COVID-19): Scaling up our testing programmes. Retrieved from https://assets.publishing.service.gov. uk/government/uploads/system/uploads/ attachment_data/file/878121/coronaviruscovid-19-testing-strategy.pdf.

Dougherty P. (2020). Rapid COVID-19 antibody detection tests: Principles and methods. Retrieved from https://www. assaygenie.com/rapid-covid19-antibodydetection-tests-principles-and-methods.

Guan, W. J., Ni, Z. Y., Hu, Y., Liang, W. H., Ou, C. Q., \& He, J. X., (2020). Clinical characteristics of 2019 novel coronavirus infection in China. New England Journal of Medicine.

Guo, Y., Cao, Q., \& Hong, Z. (2020). The origin, transmission and clinical therapies on coronavirus disease 2019 (COVID-19) outbreak an update on the status. Military Medical Research, 7(11).

Habibzadeh, P. \& Stoneman, E. K. (2020). The novel coronavirus: A bird's eye view. International Journal of Occupational and Environmental Medicine, 11(2),65-71.

Harapan, H., Naoya, I., Amanda, Y., Wira, W., Synat, K., Haypheng, T., Dewi, M., Zinatul, H., Abram, L. W., \& Mudatsir, M. (2020). Coronavirus disease 2019 (COVID-19): A literature review. Journal of Infection and Public Health, 13(5),667-673.

Harun H. N., \& Ting L. W. (2020, March 27). Malaysia shows progress in Covid-19 testing capabilities, Retrieved from https://www. nst.com.my/news/nation/2020/04/587475/ malaysia-shows-progress-covid-19-testingcapabilities-nsttv

Hisham, M., Khurram, M., \& Alimuddin, Z. Z. (2019). Therapeutic options for Middle East respiratory syndrome coronavirus (MERS$\mathrm{CoV}$ ) Possible lessons from a systematic review of SARS-CoV therapy. International Journal of Infectious Disease. 17(10), 792-798.

Huang, C., Wang, Y., Li, X., Ren, L., Zhao, J., \& $\mathrm{Hu}$, Y. (2020). Clinical features of patients infected with 2019 novel coronavirus in Wuhan, China. The Lancet, 395, 497-506.

Kent C. (2020, May 11). Different paths to the same destination: screening for Covid19. Retrieved from. https://www. medicaldevice-network.com/features/ types-of-covid-19-test-antibody-pcrantigen/ 
Kile G., Amanda W., Rachel D., Sara G., Robert W., \& Susan M. (2020). What tests could potentially be used for the screening, diagnosis and monitoring of COVID-19 and what are their advantages and disadvantages? Retrieved from https:// www.cebm.net/covid-19/what-tests-couldpotentially-be-used-for-the-screeningdiagnosis-and-monitoring-of-covid19-and-what-are-their-advantages-anddisadvantages/

Kristian, T., Louis, D., Jay, P., Grace, H., Jamie, I. F., \& Edward, J. M. (2020). A real-time dashboard of clinical trials for COVID-19. The Lancet Digital Health, 2(6),3008630088.

Lulu Y. C. (2020). Heartbreak in the Streets of Wuhan. Bloomberg. Retrieved from https://www.bloomberg.com/news/ articles/2020-03-12/heartbreak-in-thestreets-of-wuhan

Mackenzie, J. S., \& Smith, D. W. (2020). COVID-19: A novel zoonotic disease caused by a coronavirus from China: What we know and what we don't. Microbiology Australia, 37(6), 69-75.

Ministry of Health Malaysia. (2020). Ringkasan kes COVID-19 di Malaysia. Retrieved from https://www.moh.gov.my/ index.php/pages/view/2019-ncov-wuhan.

Murugesan M. \& Harun H. N. (2020, April 4), Malaysia's Covid-19 testing capacity increases with 5 new labs, New Straits Times. Retrieved from https://www.nst. com.my/news/nation/2020/04/584325/ malaysias-covid-19-testing-capacityincreases-5-new-labs

Nina W., Katherine R., Irene B. (2020). Coronavirus und Covid-19: So testet Deutschland. Retrieved from https:// www.spiegel.de/wissenschaft/medizin/ coronavirus-und-covid-19-so-testetdeutschland-a-cbb87c09-1804-45df-bb2b8895e4da91e2.
Oltermann, P. (2020). Germany's low coronavirus mortality rate intrigues experts. The Guardian. Retrieved from https:// www.theguardian.com/world/2020/mar/22/ germany-low-coronavirus-mortality-ratepuzzles-experts.

Organisation for Economic Cooperation and Development, (2020). Tackling coronavirus; contributing to global effort. Retrieved from https://www.oecd.org/ coronavirus/en/.

Paules, C. I., Marston, H. D., \& Fauci, A. S. (2020). Coronavirus infections -more than just the common cold. JAMA, 323(8),707-8.

Pti (2020). ICMR asks states not to use rapid test kits for two days. The Telegraph India. Retrieved from https://www. telegraphindia.com/india/icmr-asks-statesnot-to-use-rapid-test-kits-for-two-days/ cid/1766876.

Puja, M., Daniel, F. M., Michael, B., Emilie, S., Rachel, S. T., \& Jessica, J. M. (2020). COVID-19: Consider cytokine storm syndromes and immunosuppression. Lancet, 28(395),1033-1034.

Ragip S. (2020). Coronavirus: Turkey rejects Chinese testing kits over inaccurate results. Middle East Eye. Retrieved from https://www.middleeasteye.net/news/ coronavirus-turkey-faulty-chinese-kits-notuse

Roxanne L. \& Inti L. (2020). Chinese firm to replace exported coronavirus test kits deemed defective by Spain. Reuters. Retrieved from https://www.reuters.com/ article/us-health-coronavirus-shenzhenbioeasy-s-idUSKBN21E161

Schoeman, D. \& Fielding, B. C. (2019). Coronavirus envelope protein: Current knowledge. Virology Journal 16(69).

Schoeman, D. \& Fielding, B. C. (2019). Coronavirus envelope protein: Current knowledge. Journal of Virology, 16(69).

Shi, H., Han, X., Jiang, N., Cao, Y., Alwalid, O., $\& \mathrm{Gu}$, J. (2020). Radiological findings from 
81 patients with COVID-19 pneumonia in Wuhan, China: A descriptive study. The Lancet, 20(4), 425-34.

Tang, J. W., Tambyah, P. A., \& Hui D. S. C. (2020). Emergence of a novel coronavirus causing respiratory illness from Wuhan, China. Journal of Infection, 228, 401-406.

van Boheemen, S., de Graaf, M., Lauber, C., Bestebroer, T. M., Raj, V. S., \& Zaki, A. M. (2015). Genomic characterization of a newly discovered coronavirus associated with acute respiratory distress syndrome in humans. mBio 3(6), 473-512.

Venkat Kumar, G., Jeyanthi, V., \& Ramakrishnan, S. (2020). A short review on antibody therapy for COVID-19. New Microbes and New Infections, 35,100682.

Vojtech B. (2020). The office wrote in advance when rapid tests could fail. Even so, the state deployed them. Seznam. Retrieved from https://www.seznamzpravy.cz/clanek/ rychlotesty-neodhali-cerstve-nakazenepacienty-varoval-zdravotni-ustav-95174

Wan, Y., Shang, J., Graham, R., Baric, R. S., \& Li, F. (2020). Receptor recognition by novel coronavirus from Wuhan: An analysis based on decade-long structural studies of SARS. Journal Virology, 11(2),65-71.

Wang, N., Shi, X., Jiang, L., Zhang, S., Wang, D., \& Tong P. (2016). Structure of MERS-Cov spike receptor-binding domain complexed with human receptor DPP4. Cell Research, 23(8), 986.

Wong, K. T., Antonio, G. E., Hui, D. S., Lee, N., Yuen, E. H., \& Wu, A. (2018). Severe acute respiratory syndrome: Radiographic appearances and pattern of progression in 138 patients. Radiology, 228(2), 401-406.

World Health Organization. (2020). Coronavirus Disease 2019 (COVID-19): Situation Report, 72. Retrieved from https:// covid19.who.int/

Wrapp, D., Wang, N., \& Corbett, K. S. (2020). Cryo-EM structure of the 2019-nCoV spike in the prefusion conformation. Science, 367(6483), 1260.

Wu F., Zhao S., \& Yu B. (2020). A new coronavirus associated with human respiratory disease in China. Nature, 579, 265-269.

Xu, X., Chen, P., Wang, J., Feng, J., Zhou, H., \& $\mathrm{Li}, \quad$ X. (2020). Evolution of the novel coronavirus from the ongoing Wuhan outbreak and modeling of its spike protein for risk of human transmission. Scence China Life Sciences, 63(3),457-60.

Yin, Y. \& Wunderink, R. G. (2018). MERS, SARS and other coronaviruses as causes of pneumonia. Respirology, 23(2),130-7.

Zhou, P., Yang, X., \& Wang X. (2020). A pneumonia outbreak associated with a new coronavirus of probable bat origin. Nature, 579, 270-273.

Zhu, N., Zhang, D., Wang, W., Li, X., Yang, B., \& Song J., (2020). A novel coronavirus from patients with pneumonia in China. New England Journal of Medicine. 17(10), 792-8. 